\title{
Factors Affecting Instructional Leadership in Secondary Schools to Meet Vietnam's General Education Innovation
}

\author{
Vu Thi Mai Huong ${ }^{1}$ \\ ${ }^{1}$ Hanoi National University of Education, Vietnam \\ Correspondence: Vu Thi Mai Huong, Hanoi National University of Education, Vietnam.
}

Received: October 8, 2019

Accepted: November 15, 2019

Online Published: January 29, 2020

doi:10.5539/ies.v13n2p48

URL: https://doi.org/10.5539/ies.v13n2p48

\begin{abstract}
Currently, there is a huge demand for secondary school education worldwide especially in the developing countries such as Vietnam. School leadership is occupying a central position in educational reform. In order to meet this for the secondary school education, the Vietnamese government tries to develop effective school leadership in its education policy agenda. The aim of this study is to investigate the influence of factors on instructional leadership of principals in lower secondary education. The study was completed with 97 secondary public schools teachers and principals in the North of Vietnam. A quantitative research design was used to conduct this study. The data was analyzed through factors such as internal and external from the role of principal in instructional leadership. Research findings underline that instructional leadership is had directly by external such as "The degree of autonomy of the school for instructional activities", "Awareness of the managers and teachers about leading teaching activities" and "education innovation" more internal such as "System of guiding documents of management levels on teaching activities"; "Conditions of facilities and finance for school teaching activities" and "Principal's training level" Principals should recognize the change of the context and enhance the improvement of teachers' shared responsibility and partnership in school decision making. Therefore, the Vietnamese government should make sure to have many positive issues that may have effective instructional leadership capacity in order to improve the culture of teaching and learning in Vietnames secondary schools.
\end{abstract}

Keywords: principals' leadership, instructional leadership, context factors, educational innovation, effects

\section{Introduction}

\subsection{The Problem}

Principal's pedagogical beliefs and instructional leadership behaviors are two important variables in understanding causes for a principal's effectiveness in the accountability era. There have been a number of variables having also been shown to impact a principal's leadership effectiveness which will be a component of this study (Peariso, 2011). In particular, gender, ethnicity, educational obtainment, classroom teaching experience, primary subject taught as a classroom teacher, years of experience as a principal at their current location, overall years as an administrator, and the percentage of instructional leadership responsibilities delegated to others and to whom (Kruger, 2008; Peariso, 2011). Principals play an important role in improvement of instruction process. Principals need to organize professional development for teacher, as well as monitor teachers' teaching practices. Peariso (2011) proposes four factors for instructional leadership role of the principal. The first dimension is shared mission and clear goals. This is the factor that affecting the instructional leadership of school principal where principals are responsible to share these school goals with school community. The second dimension is continuous monitor teacher's progress. Principal needs to be more concern in supervising, encouraging and monitoring the classroom instructional practices. The third dimension is Promoting Professional Development. Principal needs to promote professional development through many programs such as peer coaching, peer-peer network which could help teachers' classroom practices and learning of the students. The fourth dimension is professional leadership. This factor shows that how principals contribute to the effectiveness of school and student performance directly and indirectly with the ways used by principals through influencing classroom and school condition.

According to the findings of many researchers performed that task type, school level, school culture and context have effect on instructional leadership perception (Leithwood \& Jantzi, 2005; Peariso, 2011; Kieleko, 2015; Buckley et al., 2004). Besides, it is discovered that internal issues organization also has effect (Msila, 2013; Toprakçı et al., 2016; Bays, 2001). 
There has been some classification of instructional leadership skills of school principals in the related literature. These classifications mainly consist of identifying and defining the school visions, missions and goals, building consensus about school goals, providing the necessary resources for teaching, coordination, management, control and evaluation of teaching and curriculum, monitoring evaluating and developing the staff, creating close relationship and cooperation between staff, regular teaching-learning climate, enabling the support from society and environment, being a role model and teaching source (Baker \& Cooper, 2005; Hallinger, 2005; Fernandez et al., 2007; Williams et al., 2005; Botha, 2004; Bays, 2001; Issa, 2012).

Principal is the most important person, not only to take care of any problems but also for achieving school's goals and objectives. Principal's role for the school is endless; among all the most important is instructional leadership. There are many factors affecting instructional leadership. They are internal factors that belong to the principals such as gender, competence, awareness. There are factors that belong to the external context. However, these factors are being evaluated separately in many different studies. Vietnam has been implementing radical education innovation from content-based education to competence-based education approach since 2018, the instructional leadership of principals has been strongly influenced by the enormous impact of context, facilities, capacity and training level, ability to adapt to change of principal. The researches on that issue have been limited.

\subsection{Literature Review}

\section{1) Leadership in teaching}

The concept of instructional leadership has been extensively studied in the 1980s and 1990s (Hallinger, 2000, 2003). There are many models and concepts that exist to explain instructional leadership. Among models and guiding leadership theory can be called Model Hallinger and Murphy (1985), Weber (1996) Model, Murphy (1990) Model, and McEwan (2009) Model. Hallinger and Murphy (1985) defined instructional leadership as the principal's behavior to promote and improve the teaching and learning process in schools related to teachers, students, parents, school plans, and management-management of schools, facilities and schools. Hallinger (2013) has developed the Key Guidance Evaluation Tool (PIMRS) that has been applied in more than 175 surveys worldwide.

Hallinger $(2009$, p. 1) views instructional leadership by school leaders as a relatively new concept that emerged in the 1980s, which called for a shift in emphasis from principals as managers or administrators to instructional or academic leaders. Hallinger (2009, p. 2), in his analysis of instructional leadership, administration, and management, argues that instructional leadership involves: setting clear goals; allocating resources for instruction; managing the curriculum; monitoring lesson plans; and evaluating teachers. It also involves those actions that the principal performs or delegates to others to promote growth in student learning. Some of the key elements that characterize instructional leadership and distinguish it from management and administration include prioritization; a focus on alignment of the curriculum, instruction and assessment standards; data analysis; a culture of continuous learning for adults; school culture and climate; visionary instructional leadership; and the variables related to instructional leadership.

The role of school leaders is not only to manage the school but also functions as instructional leaders. The effectiveness of the school depends on the school leader's instructional leadership. This study focuses on the first dimension of the instructional leadership conceptual framework. Defining a school mission is the first dimension of the framework that identifies how the school leaders practicing instructional leadership to define the school's goals (Rashdi \& Khamis, 2017).

Through constructivist learning theory instructional leader can use the principles in the theory to improve the classroom instruction and create clear academic goals. There are principles for effective teaching and learning; 1) to make connections with the student's existing knowledge structure, teaching must begin with a content and familiar experiences, 2) the knowledge given should not change the students cognitive model too extreme or drastic, 3) the teaching aimed is to empower the students with skill to be independent, and be able to use relevant information from various sources to solve the problems and challenges, and 4) the learning activities more to cooperative learning that involve with the students working in small groups and discussing to find the answer (Makgato, 2012).

School principals are expected to play a pivotal role in enhancing quality teaching and learning in their schools. The role of school leaders is not only to manage the school but also functions as instructional leaders. The effectiveness of the school depends on the school leader's instructional leadership. Alig-Mielcarek (2003) determined that instructional leadership focus on defining and communicating shared goals: meaning that the leader is responsible to establish collaboratively with staff what goals they are aspiring to attain and how they will collectively and individually achieve the outcomes for which they are striving; Monitoring and providing feedback 
on the teaching and learning process: the leader should be present to the teachers and students. The instructional leader is visible around the school, constantly communicating with everyone about standards and achievements; promoting school-wide professional development: there should be a culture of learning at all levels in the institution. Instructional leaders provide opportunities for professional development as well as data collection for improved instruction and student achievement.

2) Factors affecting teaching leadership

Considering academic achievement in terms of factors affecting instructional leadership of school principal performance is generally based on two components. The first of these is the competences of the school principal and external factor from teacher, staff, school environment, educational policy, and educational reform. Ozdemir (2019) conducted to examine the effect of the principal relating to instruction. This includes statements on identifying school goals; knowing the teacher expectations; deciding on institutional goals in conjunction with students, teachers and parents; and creating family expectations about enabling students to reach these goals. Msila (2013), Toprakç1 et al. (2016), and Bays (2001) focus on teacher and staff in each school. A supportive environment plays an importance part in instructional leadership (Leithwood \& Jantzi, 2005; Peariso, 2011; Kieleko, 2015; Buckley et al., 2004).

3) The training level, leadership capacity of the principal

The principal must be a leader, giving the right plans to develop the school in a positive direction. In the instructional leadership process, the principal of the principal is the skill of developing goals, planning, program development, communication capacity, sharing and cooperation, and motivational capacity to encourage creativity and innovation. Related to the personnel is the skill of assignment in accordance with each nature of the job to achieve high efficiency. The leadership capacity of a principal is very important to the teaching activities of the school and also motivates the learning activities and teaching and development activities. The capacity, qualifications and capacity of leaders and principals have a direct impact on the results of teaching activities. Therefore, the school always pays attention to fostering professional capacity for management staff.

Wieczorek and Manard (2018) express that the principals focused heavily on developing relationships and trust among their teachers, students, and parents. Effective instructional leaders play an important role in creating and encouraging instructional development in school; many researchers employ varying terminology in building the profiles of effective leaders, such as skills, competencies, descriptors, dimensions, and capabilities. We will summarize the concepts as though they are synonymous terms, in that they all present observable, assessable, and even potentially measurable qualities of a school leader (Hallinger, 2005; Research and Innovation for Student Learning, 2018)

Baker and Cooper (2005) found that principals with strong academic backgrounds were 3.3 times more likely to recruit, select, and retain teachers with similar academic attributes. Baker and Cooper (2005) suggested this is important since the literature from economic and educational policy research indicates that teachers with strong academic backgrounds produce better student outcomes. Fernandez et al. (2007) also found that a principal's educational attainment had a significant influence on their school's standardized test scores and student attendance rates. The backgrounds of educational leaders as classroom teachers have also shown to affect leadership outcomes. Williams et al. (2005) found that principals' years of experience correlate with high student achievement.

Botha (2004) argues that theoretical knowledge is as important as tacit and experiential knowledge. The knowledge of practice and educational theories puts principals in a better position to know the challenges teachers face when they are implementing the curriculum. The principal as the instructional leaders must be well-informed about current developments in the education sector since the instructional context is forever changing.

Bays (2001) pointed out that principals of schools whose enrolment is high have a lot of issues to address compared to principals who have lower enrolments. Principals of high enrolment schools are therefore confronted with many competing administrative and managerial responsibilities which reduce the time available to the principal for direct interaction with teachers on instruction matters.

According to Issa (2012) and Kieleko (2015), teaching load of the principal influences the effectiveness of the principals' instructional supervision. There are three basic skills of supervision-technical, human and conceptual. Each of these skills domains applies to educational and organizational roles of supervisors as well. Technical skills assume ability to use knowledge, methods to perform specific tasks. Human skills refer to one' ability and judgment in working with and through people. Conceptual skills refer to the supervisor's ability to view the schools and the educational program as a whole. Supervision requires Planning, Staffing, Coordination, 
Observation, Curriculum development and Assessment. Findings revealed that principals' supervisory competency was found to be significantly influenced by their administrative experiences (Sergiovanni, 2009; Kieleko, 2015).

\section{4) Awareness of managers and teachers on leadership of teaching activities}

Principals are often perceived to be associated with a manager's job rather than a leader's job. In fact, the principal's job is also the leadership of activities in general, leading teaching activities in particular. Currently, in Vietnam, the concept of teaching leadership is relatively new. Therefore, the principal's awareness and the teachers in the schools will directly affect the effectiveness of the teaching leader. When carrying out activities related to teaching leadership, the principal himself must become an expert in teaching activities in the school; is a bridge between the parties involved in the school's teaching activities. If the ability to connect, motivate and encourage creative sharing is confirmed, teachers and students will have many advantages in teaching and learning. The effectiveness of teaching is affirmed as a core channel to attract stakeholders to create resources for the development of the school. In addition, the school's teachers and staff, when they are good at teaching, grasp the mission, the school's second-hand will develop themselves more and more perfect, because the school is a collective each staff, teacher, and staff in the school is an individual. If you want a team to develop, each individual must develop and then grow together. Requires each teacher and manager to clearly identify and recognize the importance of teaching issues to the reputation and effectiveness of the school (Msila, 2013).

Teachers are given opportunities for professional development in order to gain effective skills for curriculum coverage. The schools make sure that the curriculum is covered so that the students have the opportunity to meet the contents of the national examinations. The schools ensure the existence of the strong cordial relationships with the parents in order to complete each other on the addressing the expectations of the students. Teachers as well as the students are recognized for their achievements in order to motivate them (Toprakç1 et al., 2016).

Bays (2001) expressed that a large number of teachers and high student enrolment is associated with emphasis on bureaucratic approach since the high span of control denies the principal enough time for individualized attention upon teachers. A small number of teachers and students mean a narrower span of control giving principals an opportunity to interact regularly with teachers during supervision hence collaboration

5) School culture actively encourages sharing, cooperation and innovation

In the traditional management model, the school manager perceives the school's goal to be clear, simple and highly stable, hence the concept of nature, the school is only a tool and methods to accomplish existing goals; In school teachers like a hired employee whose value is like a tool, if appropriate, will be used. Currently there are major changes in the concept of organization, which is where people live and develop, not just a tool to achieve the intended goal. The school organization is associated with the leader of teaching activities, not only is the workplace preparing for the future but also the place for students and teachers, the staff to grow and develop more. If the education environment is not friendly, it is difficult to prepare for the future of students as well as professional development, professional enthusiasm in teachers and school officials and employees. The development of a school-based staff will determine the school's performance. Study leaders emphasize sharing and cooperation, emphasizing motivation and encouraging innovation and creativity, thus building a culture that encourages innovation and collaboration will help improve efficiency, teaching and learning activities.

Sharm (2012) in the latest findings accounted for instructional leadership of the participant principals as leadership for overall development of students, supported commitment for overall development of students, shared decision making, involving supervisory models and continuous professional development. It also advocated the benefits of instructional leadership in terms of fulfillment of higher needs of recognition, self-esteem and self-actualization of students, teachers and the principals; shared leadership (Hallinger \& Heck, 2010).

The percentage of instructional leadership responsibilities delegated to others is another variable worth consideration. As discussed previously, principal-centered instructional leadership has been strongly influenced by transformational leadership that focuses on empowering others (Leithwood \& Jantzi, 2005). The amount of, and specifically to whom, instructional leadership is delegated to others provides an added level of depth in understanding how successful principals practice their instructional leadership in today's accountability era (Peariso, 2011).

Kieleko (2015) revealed that workload affected principals' instructional supervision. Most of the principals indicated that workload affects their position to a greater extend since their performance in the schools is judged depending on how well they are able to control and coordinate the schools in one direction.

Buckley et al. (2004) and Kieleko (2015) revealed that teaching load significantly influenced supervision 
especially on the principals' ability to observe teachers in class, give feedback after classroom observation and checking the teaching aids.

6) Renovating education and system of guiding documents of management levels on teaching activities

The objective of reform is the National Assembly's Resolution 88/2014/QH13, which stipulates: "Renovating general education textbooks and programs to create a fundamental and comprehensive change in the quality and efficiency of general education. ; combining literacy, teaching people and career orientation; contribute to transforming the heavy education of transmitting knowledge to education to develop comprehensively both in quality and capacity, harmonizing virtue, mind, body, beauty and promoting the best potential of each student. “

Implementing Resolutions of the Party, the National Assembly and the Prime Minister's Decision, the new general education program is built according to the orientation of developing the quality and capacity of learners, creating a learning and forging environment. training to help students develop harmoniously physically and mentally; become an active, confident, conscious learner with a career choice and lifelong learning; There are good qualities and capabilities necessary to become responsible citizens, cultured, diligent and creative workers, meeting the personal development needs and requirements of the construction career building and protecting the country in the era of globalization and new industrial revolution.

The implementation of the general education program sets new requirements for the pedagogical capacity of teachers and the principal's leadership in teaching activities. The decisive factor for the implementation of the subject program achieves the objectives, requires the development of student qualities and capacities as designed and built, which is the quality and competence of the staff, teachers at general education institutions, who directly implement the subject program.

Currently the new general education program has been issued. In addition, the program and annual plan related to teaching activities in schools in general, secondary schools in particular have been released and transferred to schools. However, some guiding documents are not explicit. On the other hand, the training on spiritual implementation has not been as effective as expected, leading to creating barriers in the process of implementing teaching activities in practice in each locality, each region and each school. The principal still had difficulties when he was not active, creative and encouraged to innovate in the school.

Zorlu and Arseven (2016) express that a school manager as an instructional leader is to actively take part in the school program, selection, provision and distribution of instructional materials. To achieve learning outcomes at expected levels at schools, the inputs (education program, printed materials instructional technologies, physical and financial resources, education staff and time) are to be integrated effectively. School administrators as instructional leaders are to provide teachers with necessary resources so that they can carry out education activities effectively. School administrators should set an example for school staff in making use of new and different instructional resources.

7) The autonomy level of the school for instructional activities

Autonomy has been introduced into high school education for more than ten years in both legal and implementation. The Law on the Law of 29 on the fundamental reform of education is the legal basis for managing high schools in our country to switch to the management method of taking the school as a basis. Accordingly Assigning autonomy and self-responsibility to education and training institutions; promote the role of the school council. Perform monitoring of subjects in schools and society; strengthen inspection and inspection of management agencies at all levels; ensuring democracy, openness and transparency. Education Law 2019 Specifying the role of the school in Article 60 on the duties and powers of the school with 4 contents: To publicize educational objectives, programs and plans, educational quality assurance conditions, evaluation results and educational quality accreditation; system of diplomas and certificates of the school; Organize enrollment, education, training, scientific research, transfer of training results and scientific research in accordance with functions, tasks and powers; certify or grant diplomas and certificates according to its competence; Actively propose needs, participate in teachers and workers in public schools; management and use of teachers and workers; learner management; Mobilizing, managing and using resources according to law provisions; to build material bases according to the requirements of standardization and modernization;

School autonomy is a management policy, a tool to improve the quality and effectiveness of education. The autonomy mechanism of public non-business units, whether public schools are autonomous and to what extent autonomy is completely dependent on the ability to self-guarantee expenditures. When the school is autonomous with respect to teaching and learning activities, the principal will be proactive in making teaching plans appropriate to the school practice. The members of the teacher, thanks to their autonomy, will create, take initiative 
and promote their professional and professional capacities. The degree of autonomy of the school will determine the level of creativity and flexibility for teaching activities (Research and Innovation for Student Learning, 2018).

8) Social context in exchange for instructional leadership in school

For instructional leadership, in the "digital age", effective schools need to exploit the advantages of physical resources, information and communication technology (ICT); effectively use school resource resources; and the most important point is to modernize facilities and facilities in the schools today. Currently, the trend of globalization is covering all areas. The era of digital technology development, information technology development helps people access information faster. This is an opportunity to bring applications into the process of teaching at secondary schools, contributing significantly to improving the quality of teaching activities. The role of leadership in teaching activities has also changed. Mass media and diverse sources of information make schools more selective in terms of the level of awareness of students, parents and teachers in the school. On the other hand, the principal also needs a way to encourage proper use. These factors directly affect the teaching and leadership of teaching activities. Wieczorek and Manard (2018) and Hallinger (2016) affirmed that Educational leadership scholars have asserted that broader community, school, and organizational contexts can influence and define principals' leadership practices.

Contextually responsive leadership is not only shaped by the characteristics and culture of a particularly rural sense of place, but also the particular issues and challenges that are present in the community, school systems, and the political environment.

Previous research has established that contexts of school leadership include geographic location, demographics, socioeconomic status, policy environment, and the culture of local and surrounding communities.

A recent review of the impacts of context on leadership demonstrates that community contexts of leadership vary for school leaders.

9) Resources for instructional activities

High school resources are all the factors and facilities that the school uses to accomplish its goals. These are the factors inside, outside the school, and the person in the school has control over it, controlling it for the purpose of the school. Human resources of schools are the force of teachers, officials and employees with the professional capacity of each person to participate in the school's activities. Human resources of the school can come from outside the school: lecturers, consultants, entrepreneurs ... Human resources are the most valuable resource of the school.

In terms of the different operating mechanism of financial resources for schools, including: State budget is all revenues and expenditures in the estimates decided by the competent authority to implement. Non-state financing is all school resources (monetary) that are legally collected. The physical resources of high school are all facilities used to fulfill the school's objectives including: land, property, equipment, tools, etc. of the school.

The core of high school facilities is teaching equipment. Physical resources determine the productivity and performance of the school. Information is data that has been analyzed and processed. In order to become the information that collectors have to understand and explain the content, it is important to assess the importance of that news for solving the task. The system of scientific organizational information will change the way it operates, making the structure become streamlined, flexible and tracing the necessary information in a reasonable time and cost. Information is an indispensable input for any school, and a potential reserve for the school.

The principal has many roles in the process of mobilizing resources to serve the school's teaching activities. Resources are limited but the potential of school resources is limitless, waking up the potential, turning the potential into a resource for the school depends heavily on the Principal. Therefore, the Principal must be a person: Orientation; Decision; Center; Negotiate; Invest; Model; Coach; General control, etc. about mobilizing resources for the school.

The principals focused heavily on developing relationships and trust among their teachers, students, and parents. Educational leadership scholars have asserted that broader community, school, and organizational contexts can influence and define principals' leadership practices. Rural communities' expectations of rural school leaders are very high and require a principal who is willing to engage with all stakeholders to help lead the school community.

Through a review of research and expert consultation materials, in addition, the research team used a group discussion method (qualitative research) to determine 10 criteria that are thought to influence leadership, teaching activities; the variables are interpreted as follows. 
Table 1. Interpretation of variables of the research model

\begin{tabular}{llc}
\hline Encryption & Factor & Scale \\
\hline C1 & The degree of autonomy of the school for instructional activities & $1-5$ \\
C2 & The system ate instructions from management levels on teaching activities & $1-5$ \\
C3 & Investment policies and educational development of the state and local & $1-5$ \\
C4 & Education innovation & $1-5$ \\
C5 & Development of society & $1-5$ \\
C6 & The leadership capacity of the principal & $1-5$ \\
C7 & Principal's training level & $1-5$ \\
C8 & Conditions of facilities and finance for teaching activities of the school & $1-5$ \\
C9 & Awareness of management staff and teachers about teaching activities & $1-5$ \\
C10 & School culture actively encourages sharing, cooperation and innovation & $1-5$ \\
\hline
\end{tabular}

\subsection{The Goal of the Study}

The aim of this study is to determine and measure the effect of internal and external factors on instructional leadership of secondary principals. This research indicates that in order for school principals to have a positive impact on school inputs, they need to be either instructional manager or instructional leader. They also need to spend most of their time on subjects related to teaching, learning and education in general. The studies have been included in this meta-analysis study which aims to determine the relationships between instructional leadership and various organizational variables and the effects of some particular teacher traits on their instructional leadership perceptions. Type of issue, study region, school type, school level, sample and the scales used have been dealt with as moderator variable in this study. No evidence regarding publication bias has been observed in the study (Şişman, 2016).

\section{Methodology}

\subsection{The Study Design}

Research is conducted through 2 steps. Step 1: Qualitative research by constructing concept system/scale and observed variables and adjusting observed variables in accordance with reality. Step 2: Quantitative research, using Cronbach Alpha reliability coefficient to test the degree of strictness that the items asked in the scale correlate with each other; Exploratory factor analysis (EFA) is used to identify factors that influence the process of building and developing a brand's business, which is an effective method of analyzing the groups of factors affect the research objectives, and determine the importance of each factor in the factor group.

In this study, a multilevel quantitative research design was used and data was collected using a "Effects on Instructional' Leadership Scale" developed by the researcher which is adapted from other researches into Vietnam. The scale was developed being based on previous empirical study. The validity and reliability analysis of each scale were done and it was observed that the results were at an acceptable level. Items were measured on a 5-point Likert-type scale ( $1=$ strongly disagree, $5=$ strongly agree)

\subsection{Sample and Data}

The population of the study consists of principals and teachers from economically medium province in the North of Vietnam. There are four lower secondary schools taking part in the data collection process with 55 teachers and 42 school leaders

The data had a two-level hierarchical structure: school Principals and teacher. Therefore, the study adopted the two-level linear modeling approach to obtain multi-step samples. The first step was to identify the school principals to be involved in the sample, followed by the selection of teachers. The criterion for the selection of school principals and teachers was that they had been working in these schools from 1 to more than 20 years. The majority of survey participants have a long service life of 10 to 20 years. Principals and teachers do not always agree on the problem assessment, therefore, when separating the two subjects, the comparative look will be studied, so there is a basis for debating and evaluating the factors affect. 
Table 2. Information on survey samples

\begin{tabular}{|c|c|c|c|c|c|c|c|c|c|c|c|}
\hline & & \multicolumn{2}{|c|}{$\begin{array}{l}\text { Hung Lo Secondary } \\
\text { School }\end{array}$} & \multicolumn{2}{|c|}{$\begin{array}{c}\text { Tan Duc Secondary } \\
\text { School }\end{array}$} & \multicolumn{2}{|c|}{$\begin{array}{c}\text { Song Lo Secondary } \\
\text { School }\end{array}$} & \multicolumn{2}{|c|}{$\begin{array}{c}\text { Thuy Van Secondary } \\
\text { School }\end{array}$} & \multicolumn{2}{|c|}{ Total } \\
\hline & & Number & $(\%)$ & Number & $(\%)$ & Number & $(\%)$ & Number & $(\%)$ & Number & $(\%)$ \\
\hline \multirow{3}{*}{ Participants } & Teachers & 13 & 23.63 & 16 & 29.09 & 17 & 30.09 & 9 & 17.19 & 55 & 100 \\
\hline & Manager & 9 & 21.42 & 9 & 21.42 & 13 & 30.95 & 12 & 26.21 & 42 & 100 \\
\hline & Total & 22 & 22.7 & 25 & 25.77 & 30 & 30.93 & 21 & 20.6 & 97 & 100 \\
\hline \multirow{6}{*}{ Seniority } & $<5$ year & 0 & 0 & 3 & 12 & 1 & 3.33 & 0 & 0 & 4 & 4.12 \\
\hline & 5-10 year & 7 & 31.81 & 4 & 16 & 5 & 16.67 & 2 & 9.52 & 18 & 18.55 \\
\hline & $\begin{array}{l}10-15 \\
\text { year }\end{array}$ & 5 & 22.73 & 8 & 32 & 10 & 33.33 & 7 & 33.33 & 20 & 20.61 \\
\hline & $\begin{array}{c}15-20 \\
\text { year }\end{array}$ & 8 & 45.46 & 10 & 40 & 9 & 30 & 9 & 42.85 & 36 & 37.11 \\
\hline & $>20$ year & 0 & & 0 & & 5 & 16.67 & 0 & 0 & 5 & 19.61 \\
\hline & Total & 22 & 100 & 25 & 100 & 30 & 100 & 21 & 100 & 97 & 100 \\
\hline
\end{tabular}

\section{Result}

Firstly, test the reliability of the scale showed that Cronbach's Alpha Based on Standardized Items is 0.938 . The Cronbach's Alpha coefficient of the scale is $0.938>0.8$, so the reliability is high, the scale is standard for research. At the same time, the observed variables have the correlation coefficients of variables-the total variable (Corrected Item-Total Corrected) is high ( $>0.3)$ so all the variables meet the requirement of reliability and significance for research assist.

When check the reliability of the discovery factor, we conduct a test of the reliability of factor 1 . In terms of the meaning of experimental studies, the observed coefficients of correlation variables-total (Corrected Item-Total Corrected) $<0.3$ will be removed from the ladder. Measurements and scales are accepted when Cronbach's Alpha $>0.6$. The research found that the reliability coefficient is $0.93>0.6$, so the scale is highly reliable and meaningful for research. The observed variables have variable correlation coefficients-high sum and $>0.3$, so the variables meet the reliability requirement.

In conclusion, through the above results, the observed variables are statistically significant and reach the required reliability coefficient so the factors can continue to be used in subsequent analysis.

Secondly, Analysis of the discovery factor EFA indicated the result that the number of measurement variables is 9 , the number of samples is 92 , satisfying the condition that the number of samples is 4 times greater than the number of measurement variables.

The results of KMO and Barlett tests are shown in the following table.

Table 3. KMO and Bartlett's Test

\begin{tabular}{lll}
\hline Kaiser-Meyer-Olkin Measure of Sampling Adequacy. & & .905 \\
& Approx. Chi-Square & 731.293 \\
Bartlett's Test of Sphericity & df & 45 \\
& Sig. & .000 \\
\hline
\end{tabular}

$\mathrm{KMO}$ test: we see $\mathrm{KMO}=0,905$, satisfying the requirement to perform EFA analysis, according to Kaiser (1974), $\mathrm{KMO}=0.905>0.8$.

Barlett test: Sig coefficient. $=0,000<0.05$ so we can eliminate the hypothesis of independent correlation variables (independent correlation variables that correlate with it $=1$ and correlate with other variables $=0$ ), yes meaning that variables are correlated, so we can implement EFA. Thus, data is suitable for EFA implementation.

We analyze the factors based on factor weight, factor weight $>=0.5$ is considered to have practical significance. Looking at the Rotated Componment Matrix, we see 1 column, that is, one factor is drawn from the 10 observed variables.

Thirdly, Regression analysis investigated that regression analysis was conducted to examine the relationship between the independent variables identified through the exploratory factor model with the dependent variable. We 
obtain the following result.

Table 4. Model summary

\begin{tabular}{|c|c|c|c|c|c|c|c|c|c|}
\hline \multirow[b]{2}{*}{ Model } & \multirow[b]{2}{*}{$\mathrm{R}$} & \multirow{2}{*}{$\begin{array}{c}\mathrm{R} \\
\text { Square }\end{array}$} & \multirow{2}{*}{$\begin{array}{l}\text { Adjusted R } \\
\text { Square }\end{array}$} & \multirow{2}{*}{$\begin{array}{l}\text { Std. Error of the } \\
\text { Estimate }\end{array}$} & \multicolumn{4}{|c|}{ Change Statistics } & \multirow[b]{2}{*}{ Durbin-Watsor } \\
\hline & & & & & $\begin{array}{c}\text { R Square } \\
\text { Change }\end{array}$ & F Change & df1 df2 & $\begin{array}{c}\text { Sig. F } \\
\text { Change }\end{array}$ & \\
\hline 11 & $1.000 \mathrm{a}$ & 1.000 & 1.000 & $2 \mathrm{E}-8$ & 1.000 & 36479156981701008.000 & $10 \quad 81$ & .000 & 1.724 \\
\hline
\end{tabular}

a. Predictors: (Constant), c3.10, c3.1, c3.8, c3.2, c3.7, c3.3, c3.5, c3.6, c3.4, c3.9

b. Dependent Variable: REGR factor score 1 for analysis 1

The results show that the $\mathrm{R}$ value $=1.00$ shows that the independent variables in the regression model explain the change of the dependent variable, the negligible error.

The calculation and verification of regression coefficients are shown in the following table:

The data table above shows that all independent been have $\operatorname{Sig}$ coefficient $<0.05$, so the independent variables are linearly correlated with the dependent variable.

Table 5. Coefficients ${ }^{\mathrm{a}}$

\begin{tabular}{|c|c|c|c|c|c|c|}
\hline & \multirow[t]{2}{*}{ Model } & \multicolumn{2}{|c|}{ Unstandardized Coefficients } & \multirow{2}{*}{$\begin{array}{c}\text { Standardized } \\
\text { Coefficients } \\
\text { Beta } \\
\end{array}$} & \multirow[t]{2}{*}{$\mathrm{t}$} & \multirow[t]{2}{*}{ Sig. } \\
\hline & & $\mathrm{B}$ & Std. Error & & & \\
\hline \multirow{11}{*}{1} & (Constant) & -6.403 & .000 & & -559819274.183 & .000 \\
\hline & c3.1 & .104 & .000 & .493 & 42852648.709 & .000 \\
\hline & $\mathrm{c} 3.2$ & .122 & .000 & .106 & 43805046.457 & .000 \\
\hline & c3.3 & .155 & .000 & .122 & 45748019.952 & .000 \\
\hline & c3.4 & .165 & .000 & .135 & 37096503.145 & .000 \\
\hline & $\mathrm{c} 3.5$ & .160 & .000 & .131 & 36978533.707 & .000 \\
\hline & c3.6 & .153 & .000 & .134 & 41588901.181 & .000 \\
\hline & $\mathrm{c} 3.7$ & .123 & .000 & .118 & 45694231.689 & .000 \\
\hline & $\mathrm{c} 3.8$ & .113 & .000 & .117 & 42530439.055 & .000 \\
\hline & c3.9 & .178 & .000 & .144 & 30618155.815 & .000 \\
\hline & c3.10 & .154 & .000 & .132 & 39778299.744 & .000 \\
\hline
\end{tabular}

a. Dependent Variable: REGR factor score 1 for analysis 1

Checking the multicollinearity phenomenon: The linear regression model shows that the coefficients of all dependent variables are $<2.00$ so there is no multi-linear phenomenon, the linear regression model is valid in research.

Looking at the Beta coefficient column, we find that the most influential factor to the teaching leadership is the awareness of the management staff and teachers about teaching leadership, Beta coefficient $=0.497$. 
Table 6. Summary of evaluation of influencing factors

\begin{tabular}{lcc}
\hline Factors & $\begin{array}{c}\text { Beta coefficient } \\
\text { standardized }\end{array}$ & $\begin{array}{c}\text { Impact level (greater and } \\
\text { stronger) }\end{array}$ \\
\hline $\begin{array}{l}\text { The degree of autonomy of the school for instructional activities } \\
\text { The system ate instructions from management levels on teaching }\end{array}$ & .493 & 1 \\
activities & .106 & 10 \\
Investment policies and educational development of the state and local & .122 & 7 \\
Education innovation & .135 & 3 \\
Development of society & .131 & 6 \\
The leadership capacity of the principal & .134 & 4 \\
Principal's training level & .118 & 8 \\
Conditions of facilities and finance for teaching activities of the school & .117 & 9 \\
Awareness of management staff and teachers about teaching activities & .144 & 2 \\
School culture actively encourages sharing, cooperation and innovation & .132 & 5 \\
\hline
\end{tabular}

The data table shows that the most influential factor for teaching leaders in secondary schools is: "The degree of autonomy of the school for instructional activities" and "Awareness of the managers and teachers about leading teaching activities ". The element of "education innovation" has a great influence on teaching leaders.

Factors with the evaluation results of the least impact on teaching leaders include: "System of guiding documents of management levels on teaching activities"; "Conditions of facilities and finance for school teaching activities" and "Principal's training level".

\section{Discussion}

There are many factors affecting secondary school instructional leadership. Instructional leadership is influenced by subjective and objective factors. Thus, factors outside the support can support the work of the school principal, teaching and learning activities. The goal of the teaching leader is create and sustain a competitive school, empower others to make significant decisions, provide instructional guidance, and develop and implement strategic and school- improvement plans (Leithwood \& Jantizi, 2005). According to the current regulations of the Vietnam Education Law, relevant parties are limitedly involved in the process of making school management decisions. The school is the organization that enforces the rules; the internal components of the school, such as the principal, the teacher will decide the activities of the school. Teaching activities according to the school year plan are generally regulated by direct management. The legal basis does not allow schools to select content and programs, so teaching activities have many similarities to management and compliance. Teachers' and staff's awareness of teaching leadership also greatly affects teaching and learning activities in the school. Hallinger's model of instructional leadership consists of three dimensions: defining the school's mission, managing the instructional program, and promoting a positive learning climate. These three instructional leadership dimensions are further delineated into 10 functions of instructional leadership: framing the school's goals, communicating the school's goals, supervising and evaluating instruction, curricular coordination, monitoring student progress, protecting instructional time, providing incentives for teachers, providing incentives for learning, promoting professional development, and maintaining high visibility (Hallinger \& Murphy, 1985). When awareness is not sufficient, teachers will not actively participate in the teaching leadership model, teachers are satisfied with the methods, content and expertise. Content that spreads good vision or share is also reduced. Subject teachers follow the proposed process, limiting creativity, flexibility and work motivation do not report, which directly affects the learning effectiveness of students and makes it difficult for leaders teaching. Vietnam is in the process of comprehensive education reform, education moves from content approach to capacity access. The process of teaching and learning at middle school requires changes to meet the new program (Ministry of Vietnam, 2018). Principals need a strong theoretical foundation of current knowledge about teaching and learning, practical knowledge of the beliefs and understandings of staff in the school, and applied knowledge of how to bring about development and change in those beliefs and understandings. Experimental activities are compulsory activities; therefore, the teaching vision, the steps of teaching management and the educational environment precede the requirements of change. The teaching leader will carry out both management and leadership roles. Educational reform raises the requirements of the principal's management and teaching leadership: capacity to mobilize resources for teaching, arranging and ensuring timetables, organizing activities and creating dynamics for teachers and students, improve the quality of the school's education in the direction of promoting students' abilities and associated with solving problems arising from real life. Another finding in this study is that educational policy and 
document do not have a significant direct effect on instructional. Education in Vietnam is making significant investments in equipment and facilities for teaching and learning. In many cases, human factors will help improve teaching effectiveness and the process of managing teaching activities. For the school principal, the principal's training level is related to the teaching leader. However, when leading the teaching, the leadership and management capacity is higher than the training level.

Educational leaders must have an understanding and working knowledge of research-based curriculum and instruction, instructional practices, organization of schools for greater school learning, and supplying teachers with opportunities for growth and development. A leadership model which seeks to be proactive, raise awareness of collective interests, and achieve high achievement outcomes by idealized influence, inspirational motivation, intellectual stimulation, and individualized consideration. The researches do not pay more attention to the principals maintaining recognition work by taking all the components and variables into consideration. One of the limitations of this study is the principals should call for teachers, students, and parents being involved in decision making. The model in which the different managerial variables are involved can be compared between the school principal and teachers.

\section{Conclusion}

Many factors affect the leadership of middle school students at different levels. Set in the current context of education reform in Vietnam, the elements of education policies and guidelines and new developments in the reform of the general education program are having the greatest impact on the brand. The head of the school is involved in leadership of teaching activities. Subsequent studies in the period of educational reforms introduced and achieved initial results will demonstrate the different levels of impact of the proposed factors. The key factor that underpins the teaching and learning activities to be effective is a school that attracts a variety of stakeholders in activities in general and teaching activities in particular. This needs a great effort from policy makers and the principal of each school. When there is a lack of legal basis for high school autonomy, the management capacity of the principal, especially the motivation to create motivation and create a shared environment, to work together to support each other will improve the efficiency results in leadership of teaching activities

Owing to the emphasis on the need for the instructional leadership as a requisite to meet the educational demand in the secondary school level, it is therefore, necessary for the Vietnamese school principals to be equipped with the desired characteristics that may influence the effective teaching and learning culture. In order for these initiatives to be effective, principals need to empower teachers as well as establishing the effective rapport with other stakeholders of their schools in order to effectively fulfill these roles. In addition, the principals work with teachers, staffs and stakeholders to provide instructional leadership in order to maintain effective teaching and learning culture

\section{References}

Alig-Mielcarek, J. M. (2003). A model of school success: Instructional leadership, academic press, and student achievement (Doctoral dissertation, The Ohio State University).

Baker, B. D., \& Cooper, B. S. (2005). Do principals with stronger academic backgrounds hire better teachers? Policy implications for improving high-poverty schools. Educational Administration Quarterly, 41(3), 449-479. https://doi.org/10.1177/0013161X04269609

Bays, D. A. (2001). Supervision of special education. Instruction in rural public school districts: A grounded theory (Doctoral Dissertation, Faculty of the Virginia Polytechnic Institute and State University).

Botha, R. J. (2004). Excellence in leadership: Demands on the professional school principal. South African Journal of Education, 24(3), 239-243.

Burkley, J., Schneider, M., \& Shang, Y. (2004). Organizing for Effective Early Childhood Programs and practices critical issues. Cambridge: Harvard Family Research.

Central Executive Committee of the Communist Party of Vietnam. (2013). Resolution on fundamental and comprehensive innovation of education and training, meeting the requirements of industrialization and modernization in the context of socialist market economy and international integration.

Fernandez, K., Flores, S., Huang, E., Igwe, C., Mcdonald, L., Stroud, R., ... \& Taylor, D. L. (2007). Principal performance in Texas: Tools for measuring effective school leadership. College Station, TX: Texas A\&M University.

Hallinger, P. (2005). Instructional leadership and the school principal: A passing fancy that refuses to fade away. Leadership and Policy in School, 4(3), 221-239. https://doi.org/10.1080/15700760500244793 
Hallinger, P. (2009). Leadership for 21st Century Schools: From Instructional Leadership to Leadership for Learning. Public Lecture Series of the Hong Kong Institute of Education on 23 September 2009.

Hallinger, P. (2016). Bringing context out of the shadows of leadership. Educational Management Administration \& Leadership, 1-20. https://doi.org/10.1177/1741143216670652

Hallinger, P., \& Heck, R. H. (2010). Collaborative leadership and school improvement: Understanding the impact on school capacity and student learning. School Leadership and Management. https://doi.org/10.1080/13632431003663214

Hallinger, P., \& Murphy, J. (1985), Assessing Instructional Leadership Behavior of Principals, Elementary School. https://doi.org/10.1086/461445

Issa, Y. A. (2012). Instructional factors influencing head teachers' instructional supervision practices in secondary schools in Mandera East District. Unpublished Project: University of Nairobi, Nairobi, Kenya.

Kieleko, D. M. (2015). Factors influencing principals' instructional supervision practices in public secondary schools in lower Yatta sub-country, Kitui country, Kenya. A Research Project Submitted in Partial Fulfillment of the Requirements for the Award of the Degree of Master of Education in Educational Administration, University of Nairobi, 2015.

Kruger, M. L. (2008). School Leadership, sex and gender: Welcome to difference. International Journal of Leadership in Education, 11(2), 155-168. https://doi.org/10.1080/13603120701576266

Leithwood, K., \& Jantizi, D. (2005). A review of transformational school leadership research, 1996-2005. Leadership and Policy in Schools, 4(3), 177-199. https://doi.org/10.1080/15700760500244769

Makgato, M. (2012). Identifying constructivist methodologies and pedagogic content knowledge in the teaching and learning of technology. Social and Behavioral Sciences, 47, 1398-1402. https://doi.org/10.1016/j.sbspro.2012.06.832

McEwan, E. K. (2003). 7 steps to effective instructional leadership. Thousand Oaks, CA: Corwin Press. https://doi.org/10.4135/9781483328775

Msila, V. (2013). Instructional leadership: Empowering teachers through critical reflection and journal writing. Journal of Social Sciences, 35(2), 81-88. https://doi.org/10.1080/09718923.2013.11893149

Murphy, J. (1990). Principal instructional leadership. In R. Lotto, \& P. Thurston (Eds.), Advances in educational administration: Changing perspectives on the school (Vol. 1, Part b, pp. 163-200). Greenwich, CT: JAI.

National Assembly of the Socialist Republic of Vietnam. (2014). Resolution 88/2014/QH13.

National Assembly of the Socialist Republic of Vietnam. (2019). Education law. Law No. 43/2019/QH14

Ozdemir, M. (2019). Principal leadership and students' achievement: Mediated pathways of professional community and teachers' instructional practices. KEDI Journal of Educational Policy, 16(1), 81-104. Retrieved from http://eng.kedi.re.kr

Peariso, J. F. (2011). A Study of Principals'Instructional Leadership Behaviors and Beliefs of Good Pedagogical Practice Among Effective California High Schools Serving Socioeconomically Disadvantaged and English Language Learners.

Rashdi, N., \& Khamis, M. K. (2017). Instructional Leadership perspective of private school's mission definition.

Research and Innovation for Student Learning. (2018). Principals as Instructional Leaders A Review of the Literature Research Unit.

Sergiovanni, T. J. (2009). The principalship: A reflective practice perspective. Boston: Pearson Educational Inc.

Sharma, S. (2012). Instructional leadership model through Asian principals' perspectives. In International conference on education and management innovation IPEDR (Vol. 30).

Şişman, M. (2016). Factors related to instructional leadership perception and effect of instructional leadership on organizational variables: A meta-analysis. Educational Sciences: Theory \& Practice, 16, 1761-1787. https://doi.org/10.12738/estp.2016.5.0172

Toprakçı, E., Beytekin, O. F., \& Chipala, H. C. (2016). A Case Study of Instructional Leadership in Malawian Secondary Schools. Inonu University Journal of the Faculty of Education, 17(3), 169-176. https://doi.org/10.17679/inuefd.17314606

Weber, J. (1996). Leading the instructional programs. In S. S. Piele (Ed.), School Leadership (pp. 253-278). 
Eugene, OR: Clearinghouse of Educational Management.

Wieczorek, D., \& Manard, C. (2018). Instructional Leadership Challenges and Practices of Novice Principals in Rural Schools. Journal of Research in Rural Education, 34(2).

Williams, T., Kirst, M., \& Haertel, E. (2005). Similar students, different results: Why do some schools do better? A large survey of California elementary schools serving low-income students. Mountain View, CA: EdSource.

Zorlu, H., \& Arseven, A. (2016). Instructional Leadership Behaviors of School Administrators on the Implementation of Secondary School Curricula. International Journal of Higher Education, 5(1), $276-291$. https://doi.org/10.5430/ijhe.v5n1p276

\section{Copyrights}

Copyright for this article is retained by the author(s), with first publication rights granted to the journal.

This is an open-access article distributed under the terms and conditions of the Creative Commons Attribution license (http://creativecommons.org/licenses/by/4.0/). 